\title{
Novel Approaches to Improve Myeloma Cell Killing by Monoclonal Antibodies
}

\author{
Paola Storti ${ }^{1, * \mathbb{C}}$, Federica Costa ${ }^{1}$, Valentina Marchica ${ }^{1}$, Jessica Burroughs-Garcia ${ }^{1,2}$, \\ Benedetta dalla Palma ${ }^{1}$, Denise Toscani ${ }^{1}$, Rosa Alba Eufemiese ${ }^{1}$ and Nicola Giuliani ${ }^{1}$ \\ 1 Department of Medicine and Surgery, University of Parma, 43126 Parma, Italy; federica.costa@unipr.it (F.C.); \\ valentina.marchica@unipr.it (V.M.); jib6x6@gmail.com (J.B.-G.); benedetta.dallapalma@gmail.com (B.d.P.); \\ denise.toscani@unipr.it (D.T.); eufemieserosalba@gmail.com (R.A.E.); nicola.giuliani@unipr.it (N.G.) \\ 2 Department of Medical-Veterinary Science, University of Parma, 43126 Parma, Italy \\ * Correspondence: paola.storti@unipr.it; Tel.: +39-0521-033303
}

Received: 11 August 2020; Accepted: 31 August 2020; Published: 4 September 2020

\begin{abstract}
The monoclonal antibodies (mAbs) have significantly changed the treatment of multiple myeloma (MM) patients. However, despite their introduction, MM remains an incurable disease. The mAbs currently used for MM treatment were developed with different mechanisms of action able to target antigens, such as cluster of differentiation 38 (CD38) and SLAM family member 7 (SLAMF7) expressed by both, MM cells and the immune microenvironment cells. In this review, we focused on the mechanisms of action of the main mAbs approved for the therapy of MM, and on the possible novel approaches to improve MM cell killing by mAbs. Actually, the combination of anti-CD38 or anti-SLAMF7 mAbs with the immunomodulatory drugs significantly improved the clinical effect in MM patients. On the other hand, pre-clinical evidence indicates that different approaches may increase the efficacy of mAbs. The use of trans-retinoic acid, the cyclophosphamide or the combination of anti-CD47 and anti-CD137 mAbs have given the rationale to design these types of combinations therapies in MM patients in the future. In conclusion, a better understanding of the mechanism of action of the mAbs will allow us to develop novel therapeutic approaches to improve their response rate and to overcome their resistance in MM patients.
\end{abstract}

Keywords: monoclonal antibody; multiple myeloma therapeutic targets; CD38; SLAMF7

\section{Introduction}

In recent years, the introduction of monoclonal antibodies (mAbs) targeting CD38 and the signaling lymphocytic activation molecule family member 7 (SLAMF7) represents an important step towards the treatment of relapsed/refractory multiple myeloma (RRMM) patients [1-3].

More recently, the use of mAbs is moving into the first line treatment of newly diagnosed MM patients with high rate and durable responses [2,4,5].

Although immunotherapy with mAbs represents an attractive approach because of its well-established clinical efficacy, there is substantial variability in the sensitivity and duration of the response among patients. In this review, we will specifically focus on the mAbs currently used in the treatment of MM, such as the anti-CD38 antibodies daratumumab (DARA), isatuximab (ISA) and the anti- SLAMF7 elotuzumab (ELO). We will provide a summary of their mechanisms of actions and the new strategies to improve their effectiveness and overcome resistance. 


\section{Mechanisms of Action}

\subsection{Anti-CD38 Monoclonal Antibodies}

DARA is the first CD38-targeting mAb approved in MM therapy. It is a fully human immunoglobulin G1 kappa (IgG1k mAb that targets CD38 [6]. More recently, other anti-CD38 mAbs have been developed: ISA, an IgG1-k chimeric mAb and MOR202, an IgG1- $\lambda$ fully human $\mathrm{mAb}$ [7].

Anti-CD38 antibodies kill myeloma cells by different mechanisms of action (MoA), including classical FC-dependent immune effector mechanisms, direct and immunomodulatory effects [8]. Anti-CD38 antibodies can bind the $\mathrm{Fc}$ gamma receptors ( $\mathrm{F} \gamma \mathrm{Rs}$ ) on the immune effector cells inducing the antibody-dependent cell-mediated cytotoxicity (ADCC) and antibody-dependent cellular phagocytosis (ADCP) [7]. Natural killer (NK) cells are the main mediator of ADCC by DARA, MOR202 and ISA. Also, $\mathrm{CD} 14^{+} \mathrm{CD} 16^{+}$monocytes have a role in this mechanism of MM cell killing by DARA $[8,9]$. Moreover, phagocytosis contributes to the anti-MM activity of the anti-CD38 mAbs [8]. In vitro studies have demonstrated that DARA-coated MM cells are rapidly engulfed by macrophages [10]. Recently, it has been demonstrated that, in particular, the $\mathrm{CD} 16^{+}$(Fc $\gamma$ RIIIA) subset of monocytes is fundamental in DARA MM cells-killing activity [11]. In vitro studies have demonstrated that MOR202 can induce ADCP by myeloma-associated macrophages against MM cell lines [12]. On the other hand, ISA triggers ADCP only on MM cells that present a high level of CD38 molecules on the surface [13].

Moreover, the Fc tail of the anti-CD38 mAbs can activate the complement cascade inducing the complement-dependent cytotoxicity (CDC) against MM cells [7]. DARA is the most effective inducer of CDC, while ISA can induce CDC only in a few MM samples with high expression of CD38 on plasma cells (PCs) [13].

DARA also has an immunomodulatory effect in the MM bone marrow (BM) microenvironment, depleting T regulatory cells (T regs), regulatory B cells (B regs), and myeloid-derived suppressors cells (MDSCs) $[7,14,15]$. As a result of the reduction of immuno-suppressor cells, DARA induces $\mathrm{CD}^{+}$and $\mathrm{CD}^{+}{ }^{+} \mathrm{T}$ cells expansion in MM patients and in particular the effector memory $\mathrm{CD} 8^{+} \mathrm{T}$ cells concomitant with a decrease of naïve T cells subset [15]. Similar to DARA, ISA reduces T regs and blocks the production of immune inhibitory cytokines like interleukin (IL)-10 [16]. Moreover, CD38 is an ectoenzyme involved in the metabolism of nicotinamide adenine dinucleotide (NAD+) and adenosine: NAD+ reduction leads to the development of exhausted T cells and adenosine has an immunosuppressive effect on $\mathrm{NK}$ and $\mathrm{CD}^{+}$cells $[17,18]$. Indeed, targeting CD38 with anti-CD38 mAbs could restore the immune functions.

Finally, ISA directly induces MM cell death by binding the CD38 on the cell surface, then activating the classical caspase and lysosome death pathways [19]. In contrast, neither DARA nor MOR202 showed a direct killing effect on MM cells.

The tissue expression profile of CD38 explains some of the "off target" effects of DARA. It has been reported that CD38 is also expressed by red blood cells (RBCs). Binding of DARA to CD38 on RBCs leads to panagglutination in indirect antiglobulin test, possibly masking clinically relevant alloantibodies and complicating the selection of compatible RBCs for transfusion [20]. On the other hand, in both pre-clinical studies and clinical trials, it has been reported that DARA does not induce clinically relevant hemolysis, probably, either due to the low CD38 expression levels on RBCs or the capacity of DARA to induce antigen loss on the surface of RBCs [21].

The use of therapeutic mAbs may also affect laboratory diagnostics in MM patients. It has been reported that DARA interferes with PCs detection by flow cytometry [22] and disturbs the detection and quantitation of M-protein by immunofixation electrophoresis (IFE) [23].

Clinical studies showed that DARA can be detected as an individual monoclonal band in serum IFE. Because M-protein follow-up by IFE is part of the criteria to assess the response to the treatment in MM patients, therefore, DARA band must not be confused with the endogenous M-protein of the patient. To discriminate between endogenous M-protein and DARA, a DARA-specific immunofixation 
electrophoresis reflex assay (DIRA) was developed using a mouse anti-DARA antibody [24]. Similarly, it has been reported the interference with anti-CD38 antibody for PC detection by flow cytometry that persist from four months to six months after treatment with daratumumab. Alternative mAbs may be used. VS38 antibody anti-CD38 may be used for the detection of PCs after treatment [25]. Clearly the possible interference with laboratory testing can be also seen with the other anti-CD38 therapeutic antibodies.

\subsection{Anti-SLAMF7 Monoclonal Antibody}

ELO is a humanized IgG1 mAb that targets the extracellular domain of SLAMF7, which is expressed on normal PCs and MM cells [26]. SLAMF7 is expressed at a lower level on NK cells, CD8+ $\mathrm{T}$ cells, mature dendritic cells and activated T cells [26]. The primary mechanism of action of ELO is via NK-ADCC. ELO-induced ADCC is mediated through the binding of its Fc portion with CD16 on NK cells [27]. Studies performed by Hsi et al. showed that ELO could bind SLAMF7 present on the surface of myeloma cells and directly induce the activation of NK cells via Fc receptors. The activation of NK cells triggers the release of perforin granules that target MM cells, enhancing the anti-tumor effect of ELO [27]. In a mouse model, it has also been demonstrated that ELO can induce ADCP by M1 polarized tumor associated macrophages against human MM cell lines [28].

\section{Mechanisms of Resistance}

The mechanisms involved in the acquired resistance to therapy with mAbs are not fully understood. Downregulation of the target antigen may be one of the factors that contribute to the development of mAbs resistance. However, in clinical settings, the correlation between CD38 expression before treatment and responses to DARA therapy is still controversial $[29,30]$. Studies carried by Nijhof et al. demonstrated that MM cell lines expressing higher levels of CD38 were more susceptible to DARA-mediated ADCC and CDC, compared to those cell lines with lower expression of CD38 [31]. Recently, the same group demonstrated an association between CD38 expression levels and DARA efficacy to induce cell death by ADCC and CDC. Specifically, Nijhof and colleagues showed that MM patients who achieve partial remission when treated with DARA had a higher CD38 expression level than patients who did not achieve partial remission [32]. These results suggest that CD38 expression levels before treatment can be a key determinant to achieve a positive outcome when patients are treated with this drug. On the other hand, two studies reported no differences in the levels of CD38 expression between responders and non-responders prior to the administration of DARA [29,30].

Danhof et al. reported that other factors, like an increased number of NK cells prior to the treatment, could potentiate the patient's response when treated with ELO [33]. Additionally, polymorphisms in Fc $\gamma$ RIIIa V allele (CD16a) might also be important for ELO efficacy, although these results are not conclusive [33]. The Fc $\gamma$ RIIIa gene contains allelic variations that confer the affinity of Fc $\gamma$ RIIIa to the $\mathrm{mAb}$ [27]. In a randomized phase II study of ELO and Dexamethasone, Jakubowiak and colleagues reported that patients homozygous for the high affinity allele Fc $\gamma$ RIIIa V showed a longer progression-free survival (PFS) than those who were homozygous for the low-affinity allele [33]. However, FcR polymorphisms have only a modest impact on the response to DARA and did not significantly affect the overall survival (OS) [34].

In addition, the modulation of CD38 after treatment with a $\mathrm{mAb}$ has also been studied as a possible mechanism of acquired resistance. DARA induces the release of CD38 from myeloma cells by microvesicles [35] and the CD38 expression on MM cells is decreased after DARA exposure due to the process called trogocytosis, where there is the transfer of CD38 of MM cells to monocytes and granulocytes [36]. On the other hand, in vitro studies showed that treatment with ISA does not decrease the surface expression of CD38 on MM cells [13].

In addition, DARA resistance was found to be associated with the overexpression of complement inhibitory proteins CD55 and CD59 at the time of disease progression [32]. 


\section{Improving the Efficacy of mAbs and Overcoming Resistance}

\subsection{All-Trans Retinoic Acid (ATRA)}

The expression of targets on the surface of MM cells appears to be the main determinant for the resistance to mAbs. The modulation of the expression of these targets by different agents that can re-sensitize $\mathrm{mAbs}$ seems to be a possible key to overcoming resistance to the drug. In vitro and in vivo studies showed that agents such ATRA can be used to overcome resistance by increasing the expression of CD38 in MM cells [31]. Nijhof et al. investigated the role of ATRA in cell lines and primary MM cells [31]. Specifically, they showed that treatment with ATRA significantly increased the expression of CD38 enhancing DARA-induced ADCC and CDC in vitro. Likewise, in a humanized mouse model, ATRA improved the anti-MM effect of DARA [31]. The mechanism involving the modulation of CD38 by ATRA can be explained by the presence of a retinoic acid responsive element located in the first intron of the CD38 gene [37]. Interestingly, treatment with ATRA also reduced the expression of CD55 and CD59 in MM cells isolated from both DARA-naïve patients and patients with DARA-refractory disease [32]. These studies provided the rationale for the ongoing clinical trial with ATRA and DARA to treat DARA-naïve RRMM patients. Further studies combining CD38 mAbs with ATRA are needed to potentiate and recapture $\mathrm{mAbs}$ responses.

\subsection{Anti-CD47 Monoclonal Antibody}

Among the new potential therapeutic mAbs, CD47 is emerging as a new target in the context of solid tumor and hematological malignancies. Here, we reported the potential role of targeting CD47 as a therapeutic option alone or in combination with the main drugs used in MM treatment, to explain emerging immunotherapeutic approaches.

CD47 is an integrin-associated receptor, ubiquitously expressed on the surface of many cell types including RBCs and cancer cells [38-40]. The principal role of CD47 is to inhibit the phagocytosis through the binding of the signal regulatory protein- $\alpha$ (SIRP $\alpha$ ) [41]. In particular, CD47 expressed on target cells interacts with SIRP $\alpha$ expressed on phagocytic cells, thus activating a "don't eat me" signal [42]. The inhibition of this axis promotes the killing of tumor cells by macrophages and neutrophils [43]. The CD47/SIRP $\alpha$ axis was defined as an innate immune checkpoint in several tumor models, which stimulates antigen-presenting cell function and consequently the adaptive $\mathrm{T}$ cell-mediated anti-tumor immunity [44,45]. Several studies have reported the use of anti-CD47 in hematologic malignancies with promising results as anti-tumor therapy alone or in association with drugs used in clinical practice, including MM [46-49]. Indeed, it has been reported that the use of an anti-CD47 monoclonal antibody induces phagocytosis and killing of MM cells [50,51]. Several authors reported high expression levels of CD47 on different MM cell lines and PCs obtained from MM patients [50,52]. In particular, Sun et al. confirmed that CD47 was expressed ubiquitously in several BM sub-populations. Notably, PCs represent the population with the highest expression level of CD47. Moreover, the expression of CD47 increases with advanced stage of disease, from monoclonal gammopathy of undetermined significance (MGUS) to MM [52]. Sun et al. found that anti-CD47 antibody treatment of MM cells, co-cultured with macrophages, enhanced MM-killing, suggesting the involvement of macrophages in anti-CD47-mediated phagocytosis of myeloma cells [52].

Kim et al. reported that anti-CD47 antibodies require the involvement of phagocytic cells or their progenitors such as monocytes, macrophages, and dendritic cells to perform the anti-MM activity. In particular, they observed that the treatment with anti-CD47 mAb induces phagocytosis of MM cells by macrophages derived from mouse models. In addition, they showed that the anti-CD47 treatment influences the viability of cells; however, CDC or ADCC were not observed. Furthermore, the treatment with anti-CD47 in a mouse model resulted in the inhibition of MM cell growth, without affecting BM microenvironment [50].

Although the use of anti-CD47 mAbs promotes anti-MM activity alone, it is possible to implement the antitumor effect of this drug in combination with CD38 targeting agents, such as DARA [11,53]. 
Storti et al. showed that treatment with DARA increases the MM-killing and this effect has been correlated with the presence of a subset of $\mathrm{CD} 14^{+} \mathrm{CD} 16^{+}$monocytes. Furthermore, they observed that combination treatment DARA/anti-CD47 increases the killing of MM cells that survived only DARA treatment alone [11]. For the first time, the authors reported that the inhibition of CD47, "don't eat me" antigen, enhances the anti-MM effect of DARA, shedding light on a future application of anti-CD47 $\mathrm{mAbs}$ in the therapeutic field.

Conversely, the potential role of CD47 blockade in combination with other therapies based on $\mathrm{mAbs}$ is still controversial [54-56]. Some authors reported that SLAMF7 expression is not required for CD47 blockage-induced phagocytosis in non-Hodgkin's Lymphoma models, but others opined that its role in MM may be different [54]. It has been reported that the expression of SLAMF7 on macrophages is required for phagocytosis during treatment with anti-CD47 Abs [56]. Overall, the available data showed that CD47 could represent a promising new druggable target to treat MM.

\subsection{Cyclophosphamide (Cy)}

The anti-MM effect of DARA could be enhanced by Cy, in particular through an increased ADCP. Cy has been demonstrated to induce an acute secretory activating phenotype in tumor cells, that leads to macrophage infiltration and phagocytic activity in the BM [57]. Some authors reported that exposure of MM cell lines to low doses of Cy leads to a downregulation of CD47, which greatly increases macrophage-induced ADCP of DARA-coated MM cells [58]. Moreover, the results of the Phase 1B study NCT02955810, where DARA was used in combination with bortezomib, Cy, and dexamethasone (CyBorD DARA) as initial induction before autologous stem cell transplantation, were recently published [59]. In this study, they observed a significant reduction of CD47 on MM cells, and an increase of CD64 on BM macrophages, typical of an activated phenotype. Moreover, they reported a significant increase in the levels of tumor necrosis factor-alpha (TNF- $\alpha$ ) and interferon-gamma (IFN- $\gamma$ ) in the patient's serum, consistent with an antitumor response [59].

These findings suggest that MM cells may be more susceptible to ADCP after treatment with $\mathrm{Cy}$ and DARA together [59].

\subsection{Histone Deacetylase Inhibitors (HDACi)}

Panobinostat (PANO), is a pan-HDACi able to increase the expression of CD38 by PCs from MM patients [60]. Moreover, it has been demonstrated that the ADCC effect of DARA was increased by the pre-treatment of PANO [60]. Interestingly, PANO treatment did not affect CD38 expression on other cell types such as $T$ cells [60].

Recently, Garcia-Guerrero et al. demonstrated that the specific inhibitor of the histone deacetylase 6 (HDAC6), ricolinostat, also increases CD38 RNA expression levels and CD38 molecules on the surface of MM cells. This upregulation is specific for MM cells and does not occur on T cells, leukemia, or lymphoma cells [61]. Moreover, the treatment with ricolinostat augments the ADCC by DARA against MM cell lines but not CDC effect [61].

Together, these in vitro evidence suggest that HDACi could be used in combination with DARA to potentiate the effect of the anti-CD38 $\mathrm{mAb}$.

\subsection{Urelumab: Anti-CD137 Monoclonal Antibody}

NK cells acquire CD137 on their surface after having bound a Fc tail of an antibody with their CD16 receptor. Anti-CD137 mAbs, as urelumab, have been shown to enhance T cell mediate anti-tumor immunity and anti-tumor ADCC mediated by mAbs [62,63]. Ochoa et al. demonstrated that DARA-coated and ELO-coated MM cells induced the expression of CD137 on NK cell surface with an enhanced expression of CD25 and INF- $\gamma$ production [64]. In a NOD scid gamma (NSG) mouse model reconstituted with human NK cells and MM cell lines, they have demonstrated that the treatment with urelumab in combination with DARA controls the tumor growth better than DARA alone treatment [64]. 
Moreover, phase I study combining low dose urelumab and ELO is ongoing (NCT02252263).

\section{Therapeutic Strategies Combining Anti-SLAMF7 or Anti-CD38 mAbs and Immunomodulatory Drugs (ImiDs)}

Several clinical trials evaluating the combination of anti-SLAMF7/anti-CD38 mAbs with ImiDs are currently ongoing in MM, with promising results. In this part of the review, we elucidate the rationale of these therapeutic strategies and provide a summary of mechanistic findings from pre-clinical studies in MM models.

\subsection{ImiDs and Anti-SLAMF7 mAbs}

Preliminary in vitro studies on the anti-SLAMF7 mAb, ELO, showed that the pre-treatment of either effector cells (peripheral blood mononuclear cells, PBMC) or target myeloma cells with clinically achievable doses of lenalidomide (LEN) enhanced ADCC-mediated lysis of MM cells triggered by ELO [26]. These results gave the rationale for the use of combined therapeutic strategies in MM patients. Data were confirmed by other groups using both in vitro and in vivo models of MM, which also added more details to the mechanisms behind this effect.

Specifically, Balasa et al. [65] demonstrated that ELO treatment increases NK cell recruitment to the tumor site and enhances ADCC, while LEN exerts direct cytotoxic effects against MM cells in a xenograft model [65]. On the other hand, the same group performed in vitro studies showing that the inhibition of MM cell growth after treatment with ELO and LEN was due to the modulation of NK cell function. Using a human peripheral blood lymphocytes (PBL)/myeloma co-culture model, the authors described the upregulation of IL-2R $\alpha$ and CD54 (ICAM-1) expression on NK cells. Increased TNF- $\alpha$ levels and higher production of IL- 2 by $\mathrm{CD}^{+}{ }^{+} \mathrm{CD} 56^{+}$lymphocytes in the presence of ELO+LEN compared with either agent alone was also described. TNF- $\alpha$ directly induced MM cell death, besides increasing NK cell activation; TNF- $\alpha$ neutralizing Abs reduced this effect [65]. The role of IL-2 in enhancing NK cytotoxicity and ADCC is also known [66], as well as the effect of LEN on IL-2 production by T cells [67], thus supporting the mechanist findings of this study.

More recently, Pazina et al. [68] described new trans-costimulatory signals following ELO engagement to SLAMF7. This interaction enhanced NK cell activation toward myeloma cells expressing ligands of NKp46, NKG2D, or potentially other ITAM-signaling receptors [69]. It is known that NKp46 and NKG2D are involved in NK-mediated cytotoxicity of myeloma cells [70]; however, their surface expression may be reduced on BM NK cells from MM patients [71]. Results from Pazina et al. [68] suggest that trans-costimulation by ELO enhances the signaling by these receptors, despite their reduced expression. More interestingly, the use of LEN, known to upregulate NKG2D ligand expression on myeloma cells [72,73], further increases their susceptibility to NK cell activity, thus potentially improving ELO therapeutic effect.

Overall, these studies thus explain the significant improvement of survival outcomes in RRMM patients treated with a combination of ELO and LEN.

\subsection{ImiDs and Anti-CD38 mAbs}

Similarly to ELO, the therapeutic combination of anti-CD38 mAbs with LEN or pomalidomide (POM) has shown encouraging clinical results in the treatment of RRMM patients, which are supported by preclinical data.

Van der Veer et al. [74] demonstrated the synergistic effect between DARA and LEN in the induction of ADCC cytotoxicity using an autologous system (BM mononuclear cells of MM patients), due to LEN activation of effector cells. Indeed, it is known that LEN stimulates NK cell proliferation and increases their production of IFN- $\gamma$, TNF- $\alpha$, and granzyme B [67]. However, the authors did not report any effect of LEN on DARA CDC in these assays [74]. More interestingly, an up-regulation of DARA-dependent ADCC was described in PBMC isolated from MM patients during or just after LEN treatment, thus further supporting the potential benefits from this combination [74]. 
Other studies showed that LEN enhances in vitro DARA-induced myeloma cell lysis ADCC-mediated. This effect was mediated by an increased frequency of CD3-CD56 ${ }^{+} \mathrm{NK}$ cells, with no alterations of T-cell and monocyte compartments, even in patients' refractory to LEN [75]. Ex-vivo experiments in humanized mice engrafted with MM cells from LEN refractory patients confirmed LEN ability to potentiate the DARA effect [75]. These results were in line with a study from Van der Veer et al. [76] where the synergism between DARA and LEN was more prominent in myeloma cells of patients refractory to LEN, [76] hence suggesting DARA potential to restore their susceptibility to these agents [75].

More recently, it has been suggested that vitamin D pathway activation can potentiate the synergism between LEN and MOR202-mediated ADCP [77] due to LEN ability to induce Cytochrome P450 Family 27 Subfamily B Member 1 (CYP27B1) expression in macrophages [12].

Another potential explanation for DARA-LEN synergism could be ImiDs ability to decrease the frequency of inhibitory $\mathrm{T}$ cell populations in vitro [78]. Indeed, a study by Feng et al. [16] demonstrated that LEN upregulates CD38 expression on T regs and increases the fraction of CD38-high T regs, consequently sensitizing this population to the anti-CD38, ISA [16].

In addition, a study by Bolzoni et al. [79] previously demonstrated that ImiDs in vitro treatment up-regulates CD38 expression on MM cells [79]. This finding was recently supported by Fedele et al. [80], which also described Ikaros and Aiolos degradation as a molecular mechanism behind this effect [80]. Moreover, the authors investigated the activity of DARA in combination with LEN and found a direct correlation between the additive effect of the treatment and the increased CD38 surface expression on MM cells [80]. On the other hand, no effect on CD38 expression was observed in NK cells, indicating that the synergistic effect on the effector cells is not mediated by this mechanism [80].

Lastly, Jiang et al. [19] showed that POM, more potently than LEN, enhances ISA both direct killing of MM cells, mediated by Caspase3/7 activation, and indirect cytotoxicity mediated by effector cells [19]. Moreover, POM/ ISA synergism is enhanced in CD38-high MM cells with mutated p53 [19]. These data, together with clinical POM activity against resistant MM with del (17p), support the use of $\mathrm{POM} / \mathrm{ISA}$ combination even in high-risk patients.

These pre-clinical results thus give the rationale to combine ImiDs with anti-CD38 $\mathrm{mAbs}$ in the therapy against MM.

\subsection{Sequence of Anti-SLAMF7 and Anti CD38 mAbs in RRMM}

Up today, the optimal sequence for the administration of anti-SLAM7 and anti-CD38 mAbs in RRMM patients is unknown. DARA and ELO-based regimens have never been compared head-to head in RRMM patients. However, a retrospective clinical study showed that DARA retains its response rate whether administered as the first or second $\mathrm{mAb}$ used for the treatment of RRMM. On the other hand, the response rate of ELO seems to be reduced when ELO was administered after DARA [81]. Pre-clinical data may give some suggestions on the hypothesis that the previous use of anti-CD38 mAbs may reduce the efficacy of ELO. It is known that NK cells are reduced during DARA treatment retaining the ADCC capacity [82]. However, NK reduction levels could impact on the clinical effect of ELO mainly based on the binding and the activation of NK cells [83].

Moreover, in the ELOQUENT-2 clinical study it has been reported that the greatest PFS benefit in favor of ELO treatment was obtained in RRMM patients with a times of diagnosis longer or equal to a median of 3.5 years and those in relapse after a first line of treatment [84], suggesting that the efficacy of ELO in combination with ImiDs was greater in MM patients with a less refractory disease and with few line of previous treatments. However, recent clinical data (ELOQUENT-1) indicate that the addition of ELO to LEN and Dexamethasone did not improve the PFS, as compared to the treatment with LEN and Dexamethasone alone [ClinicalTrials.gov Identifier: NCT01335399].

Overall, these clinical evidences support the hypothesis that the use of ELO would precede the use of DARA in an optimal sequence of treatment in RRMM, whereas the role of ELO in newly diagnosed MM patients remains to be defined. 


\section{Anti-BCMA Targeting Antibodies}

Along with CD38 and SLAMF/7, other possible therapeutic targets were identified in the last years to overcome MM cell drug resistance. B-cell Maturation Antigen (BCMA), also known as TNFRSF-17, is a TNF receptor (TNFR) family protein highly expressed by human MM cells [85]. BCMA has a critical role in the regulation of the survival of long-lived PCs, while it is not required in B cell differentiation as shown by the BCMA knock-out [86]. BCMA is selectively expressed by PCs but not by $B$ lymphocytes, hematopoietic stem cells and other normal tissue cells $[87,88]$. This evidence makes BCMA a suitable target for the design of an immune-therapeutic approach. A panel of anti-BCMA mAbs have been developed showing cytotoxic activity in vitro against MM cells as either a naked IgG or a drug conjugate [89]. Moreover, innovative new generation anti-BCMA mAbs as antibody-drug conjugate and bispecific have been generated [90,91].

GSK2857916 is the first therapeutic anti-BCMA antibody-drug conjugate [92]. GSK2857916 is a humanized IgG1 anti-BCMA antibody conjugated with the toxin monomethyl auristatin F (MMAF), through a non-cleavable linker, with a high affinity for BCMA [92]. In a pre-clinical study, GSK2857916 induced MM cells killing [92]. In a xenograft mouse model the treatment was able to induce a complete MM regression [92].

GSK2857916 namely Belantamab Mafodotin was investigated in monotherapy in a phase I trial in RRMM patients [93,94]. The randomized phase II trial (DREAMM-2) [95], which enrolled 196 highly pre-treated MM patients in two cohorts with a different drug schedule. All MM patients enrolled are refractory to IMIDs and PIs, and previously treated with anti-CD38 mAbs. A recent update of the study, with a median follow-up of 9 months, indicates an overall response rate (ORR) of about $30 \%$ and showed a median PFS of 2.8 and 3.9 months in the two different cohorts, respectively; 1-year Overall Survival (OS) probability was 53\%. Other studies with Belantamab Mafodotin either as single-agent or in combination with other drugs are currently ongoing. Moreover, many others anti-BCMA mAbs drug conjugate are in clinical development [96].

Another approach to target BCMA is based on bispecific antibodies (BsAbs), which deliver T cells against a target antigen through the induction of an immunological synapse [97]. BI 836909 is a bispecific T-cell engager (BiTE) designed as two linked single-chain variable fragments (scFvs) specific for BCMA and CD3 $\varepsilon$ at N-terminal and C-terminal, respectively [98]. Fase I-III clinical trial are ongoing in RRMM patients.

\section{Conclusions}

In conclusion, the introduction of mAbs have brought new immunotherapeutic approaches improving the clinical outcomes in the treatment of MM patients. However, many patients still relapse or do not respond to these agents. The unique mechanisms of action, low cytotoxicity, and safety profiles make mAbs an ideal constituent to be used in combination with current therapeutic regimens, which could improve the response rate and possibly overcome resistance.

Several mAbs able to target CD38 and SLAMF7, expressed by both MM cells and the immune microenvironment cells, have been developed. Combination therapy with IMiDs ${ }^{\circledR}$ seems to potentiate the effect of the mAbs, anti-CD38 and anti-SLAMF7, compared with single-agent treatment, reaching significant clinical effects even in RRMM patients. Figure 1 summarizes the different mechanisms of actions of the anti-CD-38 and anti-SLAMF7 mAbs approved for the treatment of MM patients.

In this context, there is a need for novel strategies to improve MM cell killing by mAbs. Pre-clinical evidence indicates that different approaches may increase the efficacy of mAbs as the use of ATRA, Cy, or the combination with the anti-CD47 and anti-CD137 mAbs. These results gave the rationale for the ongoing clinical trials on these combination therapies, which could improve MM patient treatment (Figure 1).

New mAbs have been also developed to treat MM patients, refractory to several lines of treatment including those to anti-CD38 mAbs. Among these anti BCMA mAbs seems to be more promising. 
To conclude, a better understanding of the mechanisms of action of mAbs will permit to develop novel approaches and drug combinations to improve the response rate of the mAbs and to overcome their resistance.

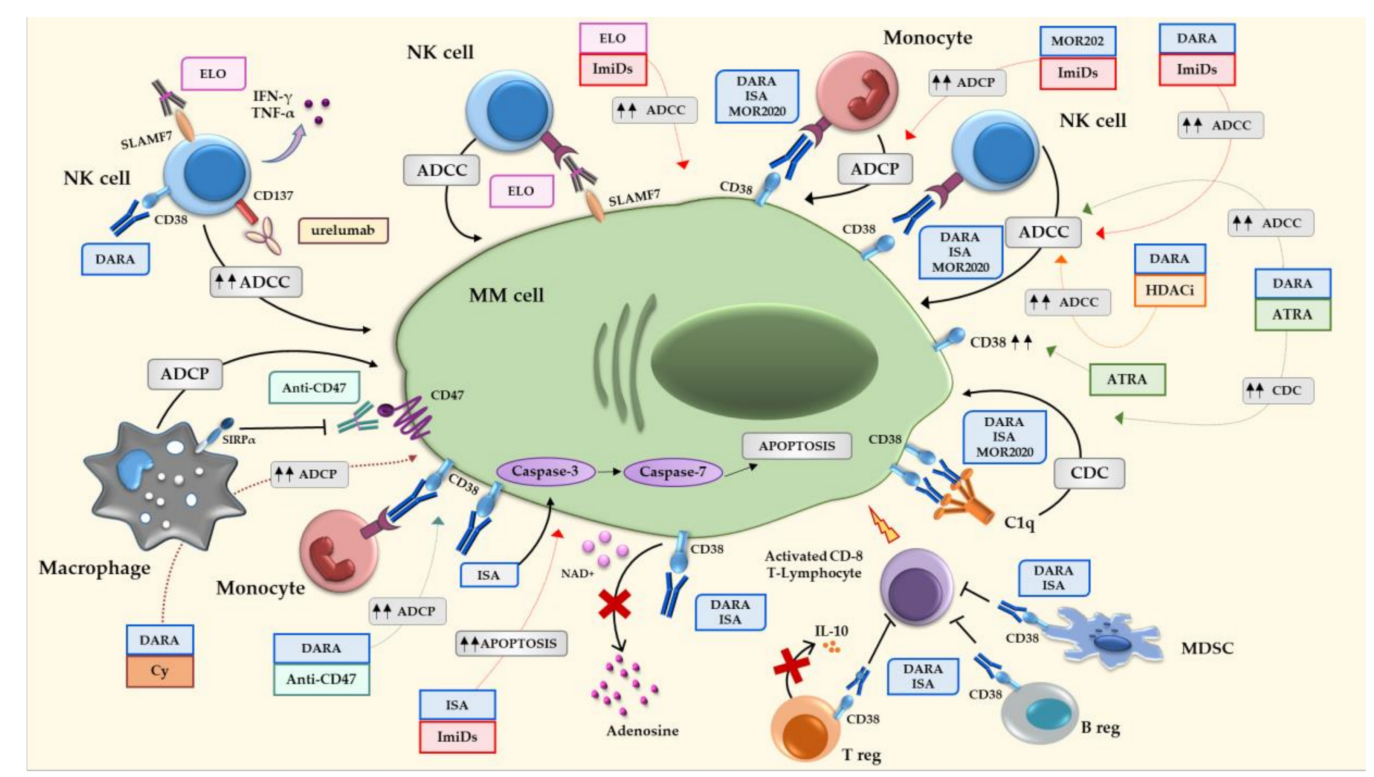

Figure 1. Mechanisms of actions of anti-CD38 and anti-SLAMF7 alone or in combination with other therapeutic agents. ADCC, antibody-dependent cell-mediated cytotoxicity; ADCP, antibody-dependent cellular phagocytosis; ATRA, all-trans retinoic acid; $\mathrm{B}$ reg, regulatory $\mathrm{B}$ cell; $\mathrm{CD}$, complement-dependent cytotoxicity; Cy, cyclophosphamide; DARA, daratumumab; ELO, elotuzumab; HDACi, histone deacetylase inhibitors; IFN- $\gamma$, interferon- $\gamma$; ImiDs, immunomodulatory drugs; ISA, isatuximab; MDSC, myeloid-derived suppressor cells; MM, multiple myeloma; NAD, nicotinamide adenine dinucleotide; NK, natural killer; SLAMF7, signaling lymphocytic activation molecule family member 7; $\mathrm{T}$ reg, $\mathrm{T}$ regulatory cell; TNF- $\alpha$, tumor necrosis factor $-\alpha$; $\operatorname{SIRP} \alpha$, signal regulatory protein- $\alpha$; IL, interleukin; C1q, complement component 1q.

Author Contributions: P.S., F.C., V.M., J.B.-G., B.d.P. and N.G. wrote the manuscript; P.S., J.B.-G., D.T., R.A.E. and N.G. reviewed the manuscript. All authors have read and agreed to the published version of the manuscript.

Funding: This work was supported in part by a grant from the Associazione Italiana per la Ricerca sul Cancro IG2017 n. 20299 and a grant from the Ministero della Salute Italiana PE-2016-02361261. N.G. received research funding and honoraria from Amgen, Bristol Mayers Squibb, Celgene, Millenium Pharmaceutical, and Janssen Pharmaceutical.

Acknowledgments: We thanks Associazione Italiana contro Leucemie, Linfomi e Mielomi ONLUS, ParmAIL for the support.

Conflicts of Interest: N.G. received research funding and honoraria from Amgen, Bristol Mayers Squibb, Celgene, Millenium Pharmaceutical, and Janssen Pharmaceutical. The other authors declare no competing financial interests.

\author{
Abbreviations \\ ADCC \\ antibody-dependent cell-mediated cytotoxicity \\ ADCP \\ antibody-dependent cellular phagocytosis \\ ATRA \\ B reg \\ CDC \\ Cy \\ all-trans retinoic acid \\ DARA \\ regulatory $\mathrm{B}$ cell \\ complement-dependent cytotoxicity \\ ELO \\ cyclophosphamide \\ HDACi histone deacetylase inhibitors \\ IFN- $\gamma \quad$ interferon- $\gamma$ \\ ImiDs immunomodulatory drugs
}




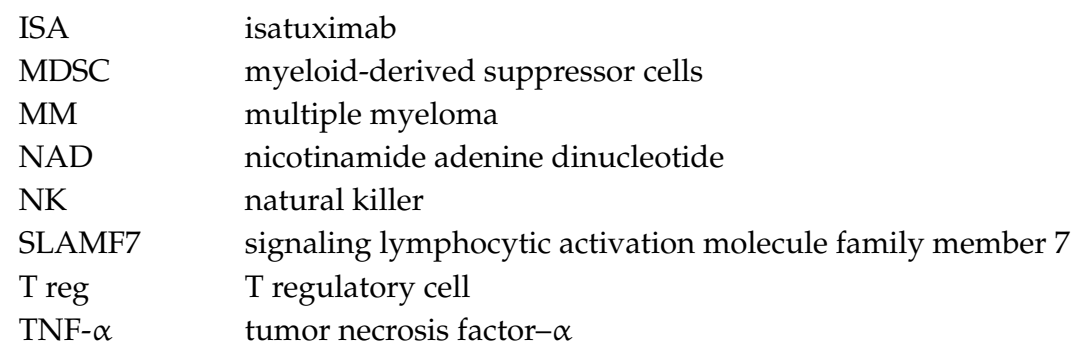

\section{References}

1. Giuliani, N.; Accardi, F.; Marchica, V.; Palma, B.D.; Storti, P.; Toscani, D.; Vicario, E.; Malavasi, F. Novel targets for the treatment of relapsing multiple myeloma. Expert Rev. Hematol. 2019, 12, 481-496. [CrossRef]

2. Musto, P.; La Rocca, F. Monoclonal antibodies in relapsed/refractory myeloma: Updated evidence from clinical trials, real-life studies, and meta-analyses. Expert Rev. Hematol. 2020, 13, 331-349. [CrossRef] [PubMed]

3. Abramson, H.N. Monoclonal Antibodies for the Treatment of Multiple Myeloma: An Update. Int. J. Mol. Sci. 2018, 19, 3924. [CrossRef] [PubMed]

4. Dimopoulos, M.A.; Jakubowiak, A.J.; McCarthy, P.L.; Orlowski, R.Z.; Attal, M.; Bladé, J.; Goldschmidt, H.; Weisel, K.C.; Ramasamy, K.; Zweegman, S.; et al. Developments in continuous therapy and maintenance treatment approaches for patients with newly diagnosed multiple myeloma. Blood Cancer J. 2020, 10, 1-19. [CrossRef] [PubMed]

5. Bonello, F.; Mina, R.; Boccadoro, M.; Gay, F. Therapeutic Monoclonal Antibodies and Antibody Products: Current Practices and Development in Multiple Myeloma. Cancers 2019, 12, 15. [CrossRef]

6. De Weers, M.; Tai, Y.-T.; Van Der Veer, M.S.; Bakker, J.M.; Vink, T.; Jacobs, D.C.H.; Oomen, L.A.; Peipp, M.; Valerius, T.; Slootstra, J.W.; et al. Daratumumab, a Novel Therapeutic Human CD38 Monoclonal Antibody, Induces Killing of Multiple Myeloma and Other Hematological Tumors. J. Immunol. 2010, 186, 1840-1848. [CrossRef]

7. Van De Donk, N.W.C.J.; Richardson, P.G.; Malavasi, F. CD38 antibodies in multiple myeloma: Back to the future. Blood 2018, 131, 13-29. [CrossRef]

8. Van De Donk, N.W.; Usmani, S.Z. CD38 Antibodies in Multiple Myeloma: Mechanisms of Action and Modes of Resistance. Front. Immunol. 2018, 9, 2134. [CrossRef]

9. Yeap, W.H.; Wong, K.L.; Shimasaki, N.; Teo, E.C.Y.; Quek, J.K.S.; Yong, H.X.; Diong, C.P.; Bertoletti, A.; Linn, Y.C.; Wong, S.C. CD16 is indispensable for antibody-dependent cellular cytotoxicity by human monocytes. Sci. Rep. 2016, 6, 34310. [CrossRef]

10. Overdijk, M.B.; Verploegen, S.; Bögels, M.; Van Egmond, M.; Van Bueren, J.J.L.; Mutis, T.; Groen, R.W.; Breij, E.; Martens, A.C.; Bleeker, W.K.; et al. Antibody-mediated phagocytosis contributes to the anti-tumor activity of the therapeutic antibody daratumumab in lymphoma and multiple myeloma. $m A b s$ 2015, 7, 311-320. [CrossRef]

11. Storti, P.; Vescovini, R.; Costa, F.; Marchica, V.; Toscani, D.; Palma, B.D.; Craviotto, L.; Malavasi, F.; Giuliani, N. $\mathrm{CD} 14+\mathrm{CD} 16+$ monocytes are involved in daratumumab-mediated myeloma cells killing and in anti-CD47 therapeutic strategy. Br. J. Haematol. 2020, 190, 430-436. [CrossRef] [PubMed]

12. Busch, L.; Mougiakakos, D.; Büttner-Herold, M.; Müller, M.J.; Volmer, D.A.; Bach, C.; Fabri, M.; Bittenbring, J.T.; Neumann, F.; Boxhammer, R.; et al. Lenalidomide enhances MOR202-dependent macrophage-mediated effector functions via the vitamin D pathway. Leukemia 2018, 32, 2445-2458. [CrossRef] [PubMed]

13. Moreno, L.; Pérez, C.; Zabaleta, A.; Manrique, I.; Alignani, D.; Ajona, D.; Blanco, L.; Lasa, M.; Maiso, P.; Rodriguez, I.; et al. The Mechanism of Action of the Anti-CD38 Monoclonal Antibody Isatuximab in Multiple Myeloma. Clin. Cancer Res. 2019, 25, 3176-3187. [CrossRef] [PubMed]

14. Croci, D.O.; Cerliani, J.P.; Dalotto-Moreno, T.; Méndez-Huergo, S.P.; Mascanfroni, I.D.; Dergan-Dylon, S.; Toscano, M.A.; Caramelo, J.J.; Garcia-Vallejo, J.J.; Ouyang, J.; et al. Glycosylation-Dependent Lectin-Receptor Interactions Preserve Angiogenesis in Anti-VEGF Refractory Tumors. Cell 2014, 156, 744-758. [CrossRef] [PubMed] 
15. Krejcik, J.; Casneuf, T.; Nijhof, I.S.; Verbist, B.; Bald, J.; Plesner, T.; Syed, K.; Liu, K.; Van De Donk, N.W.C.J.; Weiss, B.M.; et al. Daratumumab depletes CD38+ immune regulatory cells, promotes T-cell expansion, and skews T-cell repertoire in multiple myeloma. Blood 2016, 128, 384-394. [CrossRef]

16. Feng, X.; Zhang, L.; Acharya, C.; An, G.; Wen, K.; Qiu, L.; Munshi, N.C.; Tai, Y.-T.; Anderson, K.C. Targeting CD38 Suppresses Induction and Function of T Regulatory Cells to Mitigate Immunosuppression in Multiple Myeloma. Clin. Cancer Res. 2017, 23, 4290-4300. [CrossRef]

17. Horenstein, A.L.; Chillemi, A.; Quarona, V.; Zito, A.; Roato, I.; Morandi, F.; Marimpietri, D.; Bolzoni, M.; Toscani, D.; Oldham, R.J.; et al. NAD+-Metabolizing Ectoenzymes in Remodeling Tumor-Host Interactions: The Human Myeloma Model. Cells 2015, 4, 520-537. [CrossRef]

18. Vijayan, D.; Young, A.; Teng, M.W.; Smyth, M.J. Targeting immunosuppressive adenosine in cancer. Nat. Rev. Cancer 2017, 17, 709-724. [CrossRef]

19. Jiang, H.; Acharya, C.; An, G.; Zhong, M.; Feng, X.; Wang, L.; DaSilva, N.; Song, Z.; Yang, G.; Adrian, F.; et al. SAR650984 directly induces multiple myeloma cell death via lysosomal-associated and apoptotic pathways, which is further enhanced by pomalidomide. Leukemia 2015, 30, 399-408. [CrossRef]

20. De Vooght, K.M.; Oostendorp, M.; Van Solinge, W. New mAb therapies in multiple myeloma. Curr. Opin. Hematol. 2016, 23, 557-562. [CrossRef]

21. Sullivan, H.C.; Gerner-Smidt, C.; Nooka, A.K.; Arthur, C.M.; Thompson, L.; Mener, A.; Patel, S.R.; Yee, M.; Fasano, R.M.; Josephson, C.D.; et al. Daratumumab (anti-CD38) induces loss of CD38 on red blood cells. Blood 2017, 129, 3033-3037. [CrossRef] [PubMed]

22. Oberle, A.; Brandt, A.; Alawi, M.; Langebrake, C.; Janjetovic, S.; Wolschke, C.; Schütze, K.; Bannas, P.; Kröger, N.; Koch-Nolte, F.; et al. Long-term CD38 saturation by daratumumab interferes with diagnostic myeloma cell detection. Haematologica 2017, 102, e368-e370. [CrossRef] [PubMed]

23. Van De Donk, N.W.C.J.; Otten, H.G.; El Haddad, O.; Axel, A.; Sasser, A.K.; Croockewit, S.; Jacobs, J.F. Interference of daratumumab in monitoring multiple myeloma patients using serum immunofixation electrophoresis can be abrogated using the daratumumab IFE reflex assay (DIRA). Clin. Chem. Lab. Med. 2016, 54, 1105-1109. [CrossRef]

24. McCudden, C.; Axel, A.E.; Slaets, D.; Dejoie, T.; Clemens, P.L.; Frans, S.; Bald, J.; Plesner, T.; Jacobs, J.F.; Van De Donk, N.W.C.J.; et al. Monitoring multiple myeloma patients treated with daratumumab: Teasing out monoclonal antibody interference. Clin. Chem. Lab. Med. 2016, 54, 1095-1104. [CrossRef] [PubMed]

25. Mizuta, S.; Kawata, T.; Kawabata, H.; Yamane, N.; Mononobe, S.; Komai, T.; Koba, Y.; Ukyo, N.; Tamekane, A.; Watanabe, M. VS38 as a promising CD38 substitute antibody for flow cytometric detection of plasma cells in the daratumumab era. Int. J. Hematol. 2019, 110, 322-330. [CrossRef] [PubMed]

26. Tai, Y.-T.; Dillon, M.; Song, W.; Leiba, M.; Li, X.-F.; Burger, P.; Lee, A.I.; Podar, K.; Hideshima, T.; Rice, A.G.; et al. Anti-CS1 humanized monoclonal antibody HuLuc63 inhibits myeloma cell adhesion and induces antibody-dependent cellular cytotoxicity in the bone marrow milieu. Blood 2008, 112, 1329-1337. [CrossRef]

27. Hsi, E.D.; Steinle, R.; Balasa, B.; Szmania, S.; Draksharapu, A.; Shum, B.P.; Huseni, M.; Powers, D.; Nanisetti, A.; Zhang, Y.; et al. CS1, a Potential New Therapeutic Antibody Target for the Treatment of Multiple Myeloma. Clin. Cancer Res. 2008, 14, 2775-2784. [CrossRef]

28. Kurdi, A.T.; Glavey, S.V.; Bezman, N.A.; Jhatakia, A.; Guerriero, J.L.; Manier, S.; Moschetta, M.; Mishima, Y.; Roccaro, A.; Detappe, A.; et al. Antibody-Dependent Cellular Phagocytosis by Macrophages is a Novel Mechanism of Action of Elotuzumab. Mol. Cancer Ther. 2018, 17, 1454-1463. [CrossRef]

29. Pick, M.; Vainstein, V.; Goldschmidt, N.; Lavie, D.; Libster, D.; Gural, A.; Grisariu, S.; Avni, B.; Ben-Yehuda, D.; Gatt, M.E. Daratumumab resistance is frequent in advanced-stage multiple myeloma patients irrespective of CD38 expression and is related to dismal prognosis. Eur. J. Haematol. 2018, 100, 494-501. [CrossRef]

30. Viola, D.; Dona, A.; Gunes, E.G.; Troadec, E.; Wu, X.; Branciamore, S.; McDonald, T.; Ghoda, L.; Streatfield, A.; Sanchez, J.F.; et al. Immune Mediated Mechanisms of Resistance to Daratumumab. Blood 2018, $132,3201$. [CrossRef]

31. Nijhof, I.S.; Groen, R.W.; Lokhorst, H.M.; Van Kessel, B.; Bloem, A.C.; Van Velzen, J.; De Jong-Korlaar, R.; Yuan, H.; A Noort, W.; Klein, S.K.; et al. Upregulation of CD38 expression on multiple myeloma cells by all-trans retinoic acid improves the efficacy of daratumumab. Leukemia 2015, 29, 2039-2049. [CrossRef] [PubMed] 
32. Nijhof, I.S.; Casneuf, T.; Van Velzen, J.; Van Kessel, B.; Axel, A.E.; Syed, K.; Groen, R.W.; Van Duin, M.; Sonneveld, P.; Minnema, M.C.; et al. CD38 expression and complement inhibitors affect response and resistance to daratumumab therapy in myeloma. Blood 2016, 128, 959-970. [CrossRef] [PubMed]

33. Danhof, S.; Strifler, S.; Hose, D.; Kortüm, M.; Bittrich, M.; Hefner, J.; Einsele, H.; Knop, S.; Schreder, M. Clinical and biological characteristics of myeloma patients influence response to elotuzumab combination therapy. J. Cancer Res. Clin. Oncol. 2018, 145, 561-571. [CrossRef] [PubMed]

34. Van De Donk, N.W.C.J.; Casneuf, T.; Di Cara, A.; Parren, P.W.; Zweegman, S.; Van Kessel, B.; Lokhorst, H.M.; Usmani, S.Z.; Lonial, S.; Richardson, P.G.; et al. Impact of Fc gamma receptor polymorphisms on efficacy and safety of daratumumab in relapsed/refractory multiple myeloma. Br. J. Haematol. 2018, 184, 475-479. [CrossRef]

35. Chillemi, A.; Quarona, V.; Zito, A.; Morandi, F.; Marimpietri, D.; Cuccioloni, M.; Robert, O.J.; Mark, C.S.; Bolzoni, M.; Toscani, D.; et al. Generation and Characterization of Microvesicles after Daratumumab Interaction with Myeloma Cells. Blood 2015, 126, 1849. [CrossRef]

36. Krejcik, J.; Frerichs, K.A.; Nijhof, I.S.; Van Kessel, B.; Van Velzen, J.F.; Bloem, A.C.; Broekmans, M.E.; Zweegman, S.; Van Meerloo, J.; Musters, R.J.; et al. Monocytes and Granulocytes Reduce CD38 Expression Levels on Myeloma Cells in Patients Treated with Daratumumab. Clin. Cancer Res. 2017, 23, 7498-7511. [CrossRef]

37. Kishimoto, H.; Hoshino, S.-I.; Ohori, M.; Kontani, K.; Nishina, H.; Suzawa, M.; Kato, S.; Katada, T. Molecular Mechanism of Human CD38 Gene Expression by Retinoic Acid. J. Biol. Chem. 1998, 273, 15429-15434. [CrossRef]

38. Oldenborg, P.-A. CD47: A Cell Surface Glycoprotein Which Regulates Multiple Functions of Hematopoietic Cells in Health and Disease. ISRN Hematol. 2013, 2013, 1-19. [CrossRef]

39. Willingham, S.B.; Volkmer, J.-P.; Gentles, A.J.; Sahoo, D.; Dalerba, P.; Mitra, S.S.; Wang, J.; Contreras-Trujillo, H.; Martin, R.; Cohen, J.D.; et al. The CD47-signal regulatory protein alpha (SIRPa) interaction is a therapeutic target for human solid tumors. Proc. Natl. Acad. Sci. USA 2012, 109, 6662-6667. [CrossRef]

40. Oldenborg, P.-A. Role of CD47 in Erythroid Cells and in Autoimmunity. Leuk. Lymphoma 2004, 45, 1319-1327. [CrossRef]

41. Russ, A.; Hua, A.B.; Montfort, W.R.; Rahman, B.; Bin Riaz, I.; Khalid, M.U.; Carew, J.S.; Nawrocki, S.T.; Persky, D.; Anwer, F. Blocking “don't eat me" signal of CD47-SIRP $\alpha$ in hematological malignancies, an in-depth review. Blood Rev. 2018, 32, 480-489. [CrossRef] [PubMed]

42. Weiskopf, K. Cancer immunotherapy targeting the CD47/SIRP $\alpha$ axis. Eur. J. Cancer 2017, 76, 100-109. [CrossRef] [PubMed]

43. Tseng, D.; Volkmer, J.-P.; Willingham, S.B.; Contreras-Trujillo, H.; Fathman, J.W.; Fernhoff, N.B.; Seita, J.; Inlay, M.A.; Weiskopf, K.; Miyanishi, M.; et al. Anti-CD47 antibody-mediated phagocytosis of cancer by macrophages primes an effective antitumor T-cell response. Proc. Natl. Acad. Sci. USA 2013, 110, 11103-11108. [CrossRef] [PubMed]

44. Matlung, H.L.; Szilagyi, K.; Barclay, N.A.; Berg, T.K.V.D. The CD47-SIRP $\alpha$ signaling axis as an innate immune checkpoint in cancer. Immunol. Rev. 2017, 276, 145-164. [CrossRef]

45. Liu, X.; Pu, Y.; Cron, K.; Deng, L.; Kline, J.; Frazier, W.A.; Xu, H.; Peng, H.; Fu, Y.-X.; Xu, M.M. CD47 blockade triggers T cell-mediated destruction of immunogenic tumors. Nat. Med. 2015, 21, 1209-1215. [CrossRef]

46. Majeti, R.; Chao, M.P.; Alizadeh, A.A.; Pang, W.W.; Jaiswal, S.; Kenneth, D.G., Jr.; Van Rooijen, N.; Weissman, I.L. CD47 Is an Adverse Prognostic Factor and Therapeutic Antibody Target on Human Acute Myeloid Leukemia Stem Cells. Cell 2009, 138, 286-299. [CrossRef]

47. Jaiswal, S.; Jamieson, C.H.; Pang, W.W.; Park, C.Y.; Chao, M.P.; Majeti, R.; Traver, D.; Van Rooijen, N.; Weissman, I.L.; Park, C.Y. CD47 Is Upregulated on Circulating Hematopoietic Stem Cells and Leukemia Cells to Avoid Phagocytosis. Cell 2009, 138, 271-285. [CrossRef]

48. Chao, M.P.; Alizadeh, A.A.; Tang, C.; Jan, M.; Weissman-Tsukamoto, R.; Zhao, F.; Park, C.Y.; Weissman, I.L.; Majeti, R. Therapeutic antibody targeting of CD47 eliminates human acute lymphoblastic leukemia. Cancer Res. 2010, 71, 1374-1384. [CrossRef]

49. Goto, H.; Kojima, Y.; Matsuda, K.; Kariya, R.; Taura, M.; Kuwahara, K.; Nagai, H.; Katano, H.; Okada, S. Efficacy of anti-CD47 antibody-mediated phagocytosis with macrophages against primary effusion lymphoma. Eur. J. Cancer 2014, 50, 1836-1846. [CrossRef] 
50. Kim, D.; Wang, J.; Willingham, S.B.; Martin, R.; Wernig, G.; Weissman, I.L. Anti-CD47 antibodies promote phagocytosis and inhibit the growth of human myeloma cells. Leukemia 2012, 26, 2538-2545. [CrossRef]

51. Kang, M.-G.; Won, E.-J.; Choi, H.-W.; Kim, H.-R.; Park, H.-R.; Shin, J.-H.; Suh, S.-P.; Ryang, D.-W.; Shin, M.-G.; Choi, H.-J. Serum Parathyroid Hormone Is a New Potential Risk Factor in Multiple Myeloma. BioMed Res. Int. 2014, 2014, 1-7. [CrossRef] [PubMed]

52. Sun, J.; Muz, B.; Alhallak, K.; Markovic, M.; Gurley, S.; Wang, Z.; Guenthner, N.; Wasden, K.; Fiala, M.A.; King, J.; et al. Targeting CD47 as a Novel Immunotherapy for Multiple Myeloma. Cancers 2020, $12,305$. [CrossRef] [PubMed]

53. Van Bommel, P.E.; He, Y.; Schepel, I.; Hendriks, M.A.J.M.; Wiersma, V.R.; Van Ginkel, R.J.; Van Meerten, T.; Ammatuna, E.; Huls, G.; Samplonius, U.F.; et al. CD20-selective inhibition of CD47-SIRP $\alpha$ “don't eat me" signaling with a bispecific antibody-derivative enhances the anticancer activity of daratumumab, alemtuzumab and obinutuzumab. OncoImmunology 2017, 7, e1386361. [CrossRef] [PubMed]

54. He, Y.; Bouwstra, R.; Wiersma, V.R.; De Jong, M.; Lourens, H.J.; Fehrmann, R.S.N.; De Bruyn, M.; Ammatuna, E.; Huls, G.; Van Meerten, T.; et al. Cancer cell-expressed SLAMF7 is not required for CD47-mediated phagocytosis. Nat. Commun. 2019, 10, 1-8. [CrossRef] [PubMed]

55. Bouwstra, R.; Van Meerten, T.; Bremer, E. Does cancer cell-expressed SLAMF7 impact on CD47-mediated phagocytosis? Mol. Cell. Oncol. 2019, 6, 1600349. [CrossRef]

56. Chen, J.; Zhong, M.-C.; Guo, H.; Davidson, M.; Mishel, S.; Lu, Y.; Rhee, I.; Pérez-Quintero, L.-A.; Zhang, S.; Cruz-Munoz, M.-E.; et al. SLAMF7 is critical for phagocytosis of haematopoietic tumour cells via Mac-1 integrin. Nature 2017, 544, 493-497. [CrossRef]

57. Pallasch, C.; Leskov, I.; Braun, C.J.; Vorholt, D.; Drake, A.; Soto-Feliciano, Y.M.; Bent, E.H.; Schwamb, J.; Iliopoulou, B.; Kutsch, N.; et al. Sensitizing Protective Tumor Microenvironments to Antibody-Mediated Therapy. Cell 2014, 156, 590-602. [CrossRef]

58. Rigalou, A.; Ryan, A.; Natoni, A.; Chiu, C.; Sasser, K.; E O’Dwyer, M.; Dwyer, M. Potentiation of Anti-Myeloma Activity of Daratumumab with Combination of Cyclophosphamide, Lenalidomide or Bortezomib Via a Tumor Secretory Response That Greatly Augments Macrophage-Induced ADCP. Blood 2016, 128, 2101. [CrossRef]

59. O'Dwyer, M.; Henderson, R.; Naicker, S.D.; Cahill, M.R.; Murphy, P.; Mykytiv, V.; Quinn, J.; McEllistrim, C.; Krawczyk, J.; Walsh, J.; et al. CyBorD-DARA is potent initial induction for MM and enhances ADCP: Initial results of the 16-BCNI-001/CTRIAL-IE 16-02 study. Blood Adv. 2019, 3, 1815-1825. [CrossRef]

60. García-Guerrero, E.; Gogishvili, T.; Danhof, S.; Schreder, M.; Pallaud, C.; Pérez-Simón, J.A.; Einsele, H.; Hudecek, M. Panobinostat induces CD38 upregulation and augments the antimyeloma efficacy of daratumumab. Blood 2017, 129, 3386-3388. [CrossRef]

61. García-Guerrero, E.; Götz, R.; Doose, S.; Sauer, M.; Rodríguez-Gil, A.; Nerreter, T.; Kortüm, K.M.; Pérez-Simón, J.A.; Einsele, H.; Hudecek, M.; et al. Upregulation of CD38 expression on multiple myeloma cells by novel HDAC6 inhibitors is a class effect and augments the efficacy of daratumumab. Leukemia 2020, 1-14. [CrossRef] [PubMed]

62. Kohrt, H.E.; Houot, R.; Goldstein, M.J.; Weiskopf, K.; Alizadeh, A.A.; Brody, J.; Müller, A.; Pachynski, R.; Czerwinski, D.; Coutre, S.; et al. CD137 stimulation enhances the antilymphoma activity of anti-CD20 antibodies. Blood 2011, 117, 2423-2432. [CrossRef] [PubMed]

63. Kohrt, H.E.; Colevas, A.D.; Houot, R.; Weiskopf, K.; Goldstein, M.J.; Lund, P.; Mueller, A.; Sagiv-Barfi, I.; Marabelle, A.; Lira, R.; et al. Targeting CD137 enhances the efficacy of cetuximab. J. Clin. Investig. 2014, 124, 2668-2682. [CrossRef] [PubMed]

64. Ochoa, M.C.; Perez-Ruiz, E.; Minute, L.; Oñate, C.; Perez, G.; Rodriguez, I.; Zabaleta, A.; Alignani, D.; Fernandez-Sendin, M.; Lopez, A.; et al. Daratumumab in combination with urelumab to potentiate anti-myeloma activity in lymphocyte-deficient mice reconstituted with human NK cells. OncoImmunology 2019, 8, 1599636. [CrossRef] [PubMed]

65. Balasa, B.; Yun, R.; Belmar, N.A.; Fox, M.; Chao, D.T.; Robbins, M.D.; Starling, G.C.; Rice, A.G. Elotuzumab enhances natural killer cell activation and myeloma cell killing through interleukin-2 and TNF- $\alpha$ pathways. Cancer Immunol. Immunother. 2014, 64, 61-73. [CrossRef]

66. Lehmann, C.; Zeis, M.; Uharek, L. Activation of natural killer cells with interleukin 2(IL-2) and IL-12 increases perforin binding and subsequent lysis of tumour cells. Br. J. Haematol. 2001, 114, 660-665. [CrossRef] 
67. Hayashi, T.; Hideshima, T.; Akiyama, M.; Podar, K.; Yasui, H.; Raje, N.S.; Rajkumar, S.V.; Chauhan, D.; Treon, S.P.; Richardson, P.; et al. Molecular mechanisms whereby immunomodulatory drugs activate natural killer cells: Clinical application. Br. J. Haematol. 2005, 128, 192-203. [CrossRef]

68. Pazina, T.; James, A.M.; Macfarlane, A.W.; Bezman, N.A.; Henning, K.A.; Bee, C.; Graziano, R.F.; Robbins, M.D.; Cohen, A.D.; Campbell, K.S. The anti-SLAMF7 antibody elotuzumab mediates NK cell activation through both CD16-dependent and -independent mechanisms. OncoImmunology 2017, 6, e1339853. [CrossRef]

69. Martínez-Sánchez, M.V.; Periago, A.; Legaz, I.; Gimeno, L.; Mrowiec, A.; Montes-Barqueros, N.R.; Campillo, J.A.; Bolarín, J.M.; Bernardo, M.V.; Lopez-Alvarez, M.R.; et al. Overexpression of KIR inhibitory ligands (HLA-I) determines that immunosurveillance of myeloma depends on diverse and strong NK cell licensing. OncoImmunology 2015, 5, e1093721. [CrossRef]

70. Carbone, E.; Neri, P.; Mesuraca, M.; Fulciniti, M.T.; Otsuki, T.; Pende, D.; Groh, V.; Spies, T.; Pollio, G.; Cosman, D.; et al. HLA class I, NKG2D, and natural cytotoxicity receptors regulate multiple myeloma cell recognition by natural killer cells. Blood 2005, 105, 251-258. [CrossRef]

71. Costello, R.; Boehrer, A.; Sanchez, C.; Mercier, D.; Baier, C.; Le Treut, T.; Sébahoun, G. Differential expression of natural killer cell activating receptors in blood versus bone marrow in patients with monoclonal gammopathy. Immunology 2013, 139, 338-341. [CrossRef] [PubMed]

72. Fionda, C.; Abruzzese, M.P.; Zingoni, A.; Cecere, F.; Vulpis, E.; Peruzzi, G.; Soriani, A.; Molfetta, R.; Paolini, R.; Ricciardi, M.R.; et al. The IMiDs targets IKZF-1/3 and IRF4 as novel negative regulators of NK cell-activating ligands expression in multiple myeloma. Oncotarget 2015, 6, 23609-23630. [CrossRef] [PubMed]

73. Soriani, A.; Zingoni, A.; Cerboni, C.; Iannitto, M.L.; Ricciardi, M.R.; Di Gialleonardo, V.; Cippitelli, M.; Fionda, C.; Petrucci, M.T.; Guarini, A.; et al. ATM-ATR-dependent up-regulation of DNAM-1 and NKG2D ligands on multiple myeloma cells by therapeutic agents results in enhanced NK-cell susceptibility and is associated with a senescent phenotype. Blood 2009, 113, 3503-3511. [CrossRef] [PubMed]

74. Van Der Veer, M.S.; De Weers, M.; Van Kessel, B.; Bakker, J.M.; Wittebol, S.; Parren, P.W.; Lokhorst, H.M.; Mutis, T. Towards effective immunotherapy of myeloma: Enhanced elimination of myeloma cells by combination of lenalidomide with the human CD38 monoclonal antibody daratumumab. Haematologica 2010, 96, 284-290. [CrossRef] [PubMed]

75. Nijhof, I.S.; Groen, R.W.; Noort, W.A.; Van Kessel, B.; De Jong-Korlaar, R.A.; Bakker, J.M.; Bueren, J.J.L.-V.; Parren, P.W.; Lokhorst, H.M.; Van De Donk, N.W.C.J.; et al. Preclinical evidence for the therapeutic potential of CD38-targeted immuno-chemotherapy in multiple myeloma patients refractory to lenalidomide and bortezomib. Clin. Cancer Res. 2014, 21, 2802-2810. [CrossRef]

76. Van Der Veer, M.S.; De Weers, M.; Van Kessel, B.; Bakker, J.M.; Wittebol, S.; Parren, P.W.; Lokhorst, H.M.; Mutis, T. The therapeutic human CD38 antibody daratumumab improves the anti-myeloma effect of newly emerging multi-drug therapies. Blood Cancer J. 2011, 1, e41. [CrossRef]

77. Endell, J.; Samuelsson, C.; Boxhammer, R.; Strauss, S.; Steidl, S. Effect of MOR202, a human CD38 antibody, in combination with lenalidomide and bortezomib, on bone lysis and tumor load in a physiologic model of myeloma. J. Clin. Oncol. 2011, 29, 8078. [CrossRef]

78. Görgün, G.T.; Calabrese, E.; Soydan, E.; Hideshima, T.; Perrone, G.; Bandi, M.; Cirstea, D.; Santo, L.; Hu, Y.; Tai, Y.-T.; et al. Immunomodulatory effects of lenalidomide and pomalidomide on interaction of tumor and bone marrow accessory cells in multiple myeloma. Blood 2010, 116, 3227-3237. [CrossRef]

79. Bolzoni, M.; Storti, P.; Bonomini, S.; Todoerti, K.; Guasco, D.; Toscani, D.; Agnelli, L.; Neri, A.; Rizzoli, V.; Giuliani, N. Immunomodulatory drugs lenalidomide and pomalidomide inhibit multiple myeloma-induced osteoclast formation and the RANKL/OPG ratio in the myeloma microenvironment targeting the expression of adhesion molecules. Exp. Hematol. 2013, 41, 387-397. [CrossRef]

80. Fedele, P.; Willis, S.N.; Liao, Y.; Low, M.S.Y.; Rautela, J.; Segal, D.H.; Gong, J.-N.; Huntington, N.; Shi, W.; Huang, D.C.; et al. IMiDs prime myeloma cells for daratumumab-mediated cytotoxicity through loss of Ikaros and Aiolos. Blood 2018, 132, 2166-2178. [CrossRef]

81. Hoylman, E.; Brown, A.; Perissinotti, A.J.; Marini, B.L.; Pianko, M.J.; Ye, J.C.; Campagnaro, E.; Nachar, V.R. Optimal sequence of daratumumab and elotuzumab in relapsed and refractory multiple myeloma. Leuk. Lymphoma 2019, 61, 691-698. [CrossRef] [PubMed]

82. Casneuf, T.; Xu, X.S.; Adams, H.C.; Axel, A.E.; Chiu, C.; Khan, I.; Ahmadi, T.; Yan, X.; Lonial, S.; Plesner, T.; et al. Effects of daratumumab on natural killer cells and impact on clinical outcomes in relapsed or refractory multiple myeloma. Blood Adv. 2017, 1, 2105-2114. [CrossRef] [PubMed] 
83. Campbell, K.S.; Cohen, A.D.; Pazina, T. Mechanisms of NK Cell Activation and Clinical Activity of the Therapeutic SLAMF7 Antibody, Elotuzumab in Multiple Myeloma. Front. Immunol. 2018, 9, 2551. [CrossRef]

84. Dimopoulos, M.A.; Lonial, S.; Betts, K.A.; Chen, C.; Zichlin, M.L.; Brun, A.; Signorovitch, J.E.; Makenbaeva, D.; Mekan, S.; Sy, O.; et al. Elotuzumab plus lenalidomide and dexamethasone in relapsed/refractory multiple myeloma: Extended 4-year follow-up and analysis of relative progression-free survival from the randomized ELOQUENT-2 trial. Cancer 2018, 124, 4032-4043. [CrossRef] [PubMed]

85. Novak, A.J.; Darce, J.R.; Arendt, B.K.; Harder, B.; Henderson, K.; Kindsvogel, W.; Gross, J.A.; Greipp, P.R.; Jelinek, D.F. Expression of BCMA, TACI, and BAFF-R in multiple myeloma: A mechanism for growth and survival. Blood 2004, 103, 689-694. [CrossRef]

86. O'Connor, B.P.; Raman, V.S.; Erickson, L.D.; Cook, W.J.; Weaver, L.K.; Ahonen, C.; Lin, L.-L.; Mantchev, G.T.; Bram, R.J.; Noelle, R.J. BCMA Is Essential for the Survival of Long-lived Bone Marrow Plasma Cells. J. Exp. Med. 2004, 199, 91-98. [CrossRef]

87. Carpenter, R.O.; Evbuomwan, M.O.; Pittaluga, S.; Rose, J.J.; Raffeld, M.; Yang, S.; Gress, R.E.; Hakim, F.T.; Kochenderfer, J.N. B-cell maturation antigen is a promising target for adoptive T-cell therapy of multiple myeloma. Clin. Cancer Res. 2013, 19, 2048-2060. [CrossRef]

88. Seckinger, A.; Delgado, J.A.; Moser, S.; Moreno, L.; Neuber, B.; Grab, A.; Lipp, S.; Merino, J.; Prósper, F.; Emde, M.; et al. Target Expression, Generation, Preclinical Activity, and Pharmacokinetics of the BCMA-T Cell Bispecific Antibody EM801 for Multiple Myeloma Treatment. Cancer Cell 2017, 31, 396-410. [CrossRef]

89. Ryan, M.C.; Hering, M.; Peckham, D.; McDonagh, C.F.; Brown, L.; Kim, K.M.; Meyer, D.L.; Zabinski, R.F.; Grewal, I.S.; Carter, P.J. Antibody targeting of B-cell maturation antigen on malignant plasma cells. Mol. Cancer Ther. 2007, 6, 3009-3018. [CrossRef]

90. Tai, Y.-T.; Anderson, K.C. Targeting B-cell maturation antigen in multiple myeloma. Immunother. 2015, 7, 1187-1199. [CrossRef]

91. Cho, S.-F.; Lin, L.; Xing, L.; Li, Y.; Yu, T.; Anderson, K.C.; Tai, Y.-T. BCMA-Targeting Therapy: Driving a New Era of Immunotherapy in Multiple Myeloma. Cancers 2020, 12, 1473. [CrossRef] [PubMed]

92. Tai, Y.-T.; Mayes, P.A.; Acharya, C.; Zhong, M.Y.; Cea, M.; Cagnetta, A.; Craigen, J.; Yates, J.; Gliddon, L.; Fieles, W.; et al. Novel anti-B-cell maturation antigen antibody-drug conjugate (GSK2857916) selectively induces killing of multiple myeloma. Blood 2014, 123, 3128-3138. [CrossRef] [PubMed]

93. Trudel, S.; Lendvai, N.; Popat, R.; Voorhees, P.M.; Reeves, B.; Libby, E.N.; Richardson, P.G.; Hoos, A.; Gupta, I.; Bragulat, V.; et al. Antibody-drug conjugate, GSK2857916, in relapsed/refractory multiple myeloma: An update on safety and efficacy from dose expansion phase I study. Blood Cancer J. 2019, 9, 37. [CrossRef] [PubMed]

94. Trudel, S. Incorporating isatuximab in the treatment of multiple myeloma. Lancet 2019, 394, $2045-2047$. [CrossRef]

95. Lonial, S.; Lee, H.C.; Badros, A.; Trudel, S.; Nooka, A.K.; Chari, A.; Abdallah, A.-O.; Callander, N.; Lendvai, N.; Sborov, D.; et al. Belantamab mafodotin for relapsed or refractory multiple myeloma (DREAMM-2): A two-arm, randomised, open-label, phase 2 study. Lancet Oncol. 2020, 21, 207-221. [CrossRef]

96. Abramson, H.N. B-Cell Maturation Antigen (BCMA) as a Target for New Drug Development in Relapsed and/or Refractory Multiple Myeloma. Int. J. Mol. Sci. 2020, 21, 5192. [CrossRef]

97. Velasquez, M.P.; Bonifant, C.; Gottschalk, S. Redirecting T cells to hematological malignancies with bispecific antibodies. Blood 2018, 131, 30-38. [CrossRef]

98. Hipp, S.; Tai, Y.-T.; Blanset, D.; Deegen, P.; Wahl, J.; Thomas, O.; Rattel, B.; Adam, P.J.; Anderson, K.C.; Friedrich, M. Erratum: A novel BCMA/CD3 bispecific T-cell engager for the treatment of multiple myeloma induces selective lysis in vitro and in vivo. Leukemia 2017, 31, 2278. [CrossRef]

(C) 2020 by the authors. Licensee MDPI, Basel, Switzerland. This article is an open access article distributed under the terms and conditions of the Creative Commons Attribution (CC BY) license (http://creativecommons.org/licenses/by/4.0/). 